\title{
Housing Collateral Value, Debt Level and Corporate Investment
}

\author{
Huihui Li \\ Institute of Economics, Jinan University, Guangzhou, China \\ Email: lihuihui2016@sina.com
}

How to cite this paper: Li, H.H. (2019) Housing Collateral Value, Debt Level and Corporate Investment. Modern Economy, 10, 429-443.

https://doi.org/10.4236/me.2019.102029

Received: January 16, 2019

Accepted: February 10, 2019

Published: February 13, 2019

Copyright (C 2019 by author(s) and Scientific Research Publishing Inc. This work is licensed under the Creative Commons Attribution International License (CC BY 4.0).

http://creativecommons.org/licenses/by/4.0/

\begin{abstract}
This paper uses the micro data of Chinese listed companies from 2003 to 2015 and the house price data of each province to study the relationship and the mechanism between the housing collateral value of listed companies and the company's investment. The study found that corporate investment is positively correlated with the value of housing collateral and the housing collateral value has a positive impact on corporate investment by acting on debt capacity. The results show that there is a collateral channel between the housing collateral value and the company's investment, which provides direct evidence for the positive impact of the housing collateral value to corporate investment.
\end{abstract}

\section{Keywords}

Housing Collateral Value, Collateral Channel, Mediating Effect

\section{Introduction}

From the late 1990s to 2006, real estate prices in many countries soared. This round of real estate boom and stock market boom together set off a global financial crisis. Since 2003, China has also joined the ranks of countries with rapidly rising housing prices. Although most countries experienced the short-term stagnation of the housing market caused by the financial crisis in 2008, after the financial crisis, a series of loose monetary policies issued by the state were effective to stimulate the real estate market, and the Chinese real estate market has rebounded rapidly since 2009 [1].

Real estate is different from ordinary financial assets, and its channels of influence on the economy include the Wealth Effect, the Crowding Out Effect and the Collateral Channel [2]. The Collateral Channel discussed in this paper refers to the property-owned company using real estate as collateral to alleviate the 
high borrowing costs paid by the company in the lending market due to information asymmetry and incomplete contract problems, thereby alleviating the company's external financing constraints and improving its credibility of the financial sector. As an important engine of China's economic growth, the real estate price continues to rise, not only leading to financial imbalances, harming financial stability [3], but also affecting the credit demand and supply through the collateral [4] [5], and further influence the investment level of micro-enterprises under the influence of the bank's feedback-mechanism [6].

Previous studies on mortgage value and investment generally discussed the impact of macro-exogenous shocks such as the oil crisis and the collapse of the Japanese real estate bubble on corporate investment [7] [8]. In fact, macro exogenous shocks are uncommon. In recent years, scholars have found that in addition to the impact of macro-exogenous shocks, the dramatic changes in property prices are also suitable for studying the mortgage effect of property, and they use the change of local property prices as a substitute for the fluctuation of mortgage value to study the impact of the fluctuation of property mortgage value on the company's decision-making [9] [10]. They found that the value of mortgage assets has a decisive role in the optimal decision-making of enterprises.

This paper adopts the micro panel data of listed companies in China from 2003 to 2015, and uses the housing market value as a substitute variable for housing collateral value. Based on the mediating effect model, it models the collateral value, the debt level and company's investment, and studies the relationship and its mechanism between collateral value and changes in corporate investment. The results of this paper show that controlling the individual effect and annual effect of the company, the collateral value of the house has a significant positive impact on the company's investment, and according to the principle of testing the intermediary effect, named the step-by-step test method [11], the collateral value of the house affects the company's investment and the empirical results is significant, but the mechanism of it is part of the mediating effect, not the full mediating effect. In addition to using the Office Building Price, this paper also uses the Price of the Commercial Housing and the House Price to match the company's building for calculating the collateral value of the property. It is found that there is still a significant positive relationship between the collateral value of the house and the company's investment.

Compared with the existing literature, the contributions of this paper mainly include the following. First, this paper uses the micro data and house price data of listed companies to analyze the role of mortgage value and corporate investment from the perspective of the mediating effect model for the first time. In other words, there is a mediating effect between the company's investments based on the debt level. Secondly, this paper verifies that there is a positive mediating effect between the mortgage value of the company's finance and the company's investment through the debt level, which means that the mortgage value of the property increases results in increases of the debt, and then makes the enterprise investment increasing finally. Thirdly, this paper systematically 
discusses the relationship between property mortgage value and investment and its mechanism, which enriches the research on the mortgage effect of real estate, and provides empirical evidence for the microscopic transmission mechanism of real estate mortgage value.

The following contents of this paper include the literature review in the second part, the empirical model and data of in the third part, the empirical research in the fourth part and the conclusion of the last part.

\section{Literature Review}

As for the relationship between the value of collateral and corporate financing and investment, some scholars have theoretically demonstrated it. Fisher first pointed out that the sharp decline in the value of assets would undermine the commercial credit of the entire society, resulting in a reduction in corporate investment [12]. Kiyotaki and Moore argue that in the asymmetric information market, due to the interaction mechanism between the value of collateral and corporate investment, the impact of collateral price shock on corporate investment has the characteristics of circulation and acceleration. Consistent with the findings of Kiyotaki and Moore, the financial accelerator theory proposed by Bernanke and Gertler also stresses the spiral expansion effect between collateral value and corporate investment [13]. Tirole constructed a theoretical model based on the contract theory, which proved that mortgage is an important mechanism to reduce information asymmetry between entrepreneurs and external investors. He pointed that if enterprisers mortgage productive assets, then the mortgage assets will help to increase the level of external financing for the business [14].

In empirical research, the early literature focused on the impact of collateral value on the company's debt. Benmelech and Garmaise used the liquidation value of mortgage assets as a proxy variable for the value of mortgage assets, validating the positive relationship between the value of mortgage assets and corporate liabilities [15]. Schmalz based on the administrative data of France from 1992 to 2002, comparing the tenants affected by the impact of the mortgage value of the same area, the house owners who are affected by the mortgage value of the property but cannot mortgage the real estate again, and are mortgaged by the property. The level of debt of the homeowner affected by the shock of value and unsecured record, found that the change in the value of the collateral is significantly positively correlated with liabilities of the real estate owner [16].

There are also many studies that believe that the liquidation value of mortgage as-sets is decisive for the company's optimal debt decision. The liquidation value is the minimum amount of debt that the business manager promises to pay to the creditor. Benmelech proposed that the resettability of mortgage assets can measure the liquidation value of mortgage assets, and the high-recovery mortgage assets have higher liquidation value. He measures the liquidation value of the company's mortgage assets with resettability, and empirically verifies Companies with high liquidation value of mortgage assets are usually able to raise 
large loans at lower interest rates [15]. Benmelech and Bergman used American Airlines data to empirically study the company's collateral liquidation value and the renegotiation ability of both borrowers and lenders to violate the restrictive clauses, and found that when the financial situation of American Airlines deteriorated and the liquidation value of its mortgage assets was low, the success rate of airlines launching renegotiation will be higher finally [17].

In recent years, more and more literature has further studied the relationship between the value of collateral and the company's investment behavior. Lamont used the 1986 oil crisis to study the impact of the mortgage value shock caused by the oil crisis on non-oil sector investment, and found that the adverse impact of the oil group's mortgage value has a negative relationship with the non-oil sector investment. Broun shows that enterprises with high asset tangibility can use tangible assets as collateral to obtain more external financing. Almeida further verified that companies with financing constraints and high tangible assets rate can help to improve the company's external financing capabilities, thereby increasing the company's investment level [18]. Gan used the bursting of the Japanese real estate market bubble as an exogenous shock to the value of collateral. It was found that the impact of the collateral value caused by the bursting of the real estate market bubble made a large number of artisanal manufacturing companies to reduce their investment, and the one hold more real estate before the crisis, the more the company's investment level declines. Chaney uses company's data to calculate the company's real estate market value during the sample period, replaces the exogenous shock with real estate market value fluctuations, and examines the response of the company's investment level to the company's real estate unit value changes under the effect of the mortgage channel. Scholars Zeng and Wu follow the empirical framework of Chaney, using the historical data of Chinese listed companies' buildings and buildings, matching the regional housing price index to test the company's real estate value fluctuations on the company's investment changes [19]. The impact of the real estate mortgage value and the company's investment level has a significant positive correlation, the mortgage channel effect was established in China. Luo and Zhou believe that real estate is not only an important production factor of enterprises, but also can be used as collateral to help enterprises finance [20]. They used the financial statement data and off-balance sheet data of listed companies in China from 2003 to 2010 to empirically test the relationship between real estate prices and corporate investment, and found that real estate prices affect corporate investment behavior through cost effects and liquidity premium effects. In addition, Chaney also used the price fluctuations of all French companies as a real estate mortgage shock in his later research. It is verified that the change of real estate mortgage value not only affects the company's investment decision under the collateral channel, it also affects the company's employment level.

The theoretical research on collateral value and corporate investment behavior was sufficient. Most of the empirical research focuses on the verification of the relationship between collateral value and corporate investment. But a few 
documents based on the issue of the financing constraints, the collateral channel of real estate mortgage value. In fact, real estate mortgages are one of the important ways to alleviate corporate financing constraints [21]. The rise in property collateral value will not only enhance the company's debt capacity, but also increase the company's investment.

\section{The Model and Data}

\subsection{The Model}

In order to test the relationship and the mechanism among mortgage value, debt capacity and the company investment from an empirical perspective, this paper constructs the following model for measuring the mediating effect of the relationship and mechanism between the mortgage value and the investment of the company.

$$
\begin{gathered}
\text { Investment }_{i t}=\alpha_{i}+\tau_{t}+c \text { Revalue }_{i t}+\delta X_{i, t-1}+\varepsilon_{i t} \\
\text { Debt }_{i t}=\alpha_{i}+\tau_{t}+a \text { Revalue }_{i t}+\delta X_{i, t-1}+\varepsilon_{i t} \\
\text { Investment }_{i t}=\alpha_{i}+\tau_{t}+c^{\prime} \text { Revalue }_{i t}+b \text { Debt }_{i t}+\delta X_{i, t-1}+\varepsilon_{i t}
\end{gathered}
$$

In this model, $i$ and $t$ represents the company and the year respectively, Investment $_{i t}$ is investment in the year, Revalue ${ }_{i t}$ is the company's collateral value, Debt $_{i t}$ is the company's debt, $X_{i, t-1}$ is a series of company-level control variables, $\alpha_{i}$ represents the company's fixed effect, which controls the heterogeneity between companies. $\tau_{t}$ represents a time-fixed effect which controlling macroeconomic factors that change over time during the sample period. $\varepsilon_{i t}$ is as an error term. In formula (2), the control variables $X_{i, t-1}$ include the company size, the establishment period, the shareholding ratio of the first largest shareholder, the proportion of state-owned shares, the book value ratio of market value, and the profit margin of assets. In models (1) and (3), control variables $X_{i, t-1}$ also include cash flow and debt ratio. In order to avoid the endogenous problem caused by the control variable and the explanatory variable, some control variables are delayed by one period, and the other part of the control variable is divided by the lag of the first period of fixed assets. The specific variables are defined below.

According to the principle of step-by-step to test the mediating effect, the coefficient of $c$ in formula (1) measures the total effect of the collateral value on the company's investment; the coefficient $a$ in formula (2) is used to test the effect of the collateral value on the intermediary variable named debt; the coefficient $c^{\prime}$ of (3) is the direct effect of the collateral value on the investment after controlling the impact of the company's liabilities; the coefficient $b$ is the effect of the debt of the company on the investment after controlling the impact of the collateral value of the property on the investment. According to a study by MacKinnon, the coefficient $c$ measure measures the indirect effect, and the coefficient $a b$ measures the direct effect. In the mediating effect model, the indirect effect is equivalent to the mediating effect. 


\subsection{Variable Definition}

The variables are defined as shown in Table 1 , where Revalue 1 , Revalue 2, Revalue 3, Revalue 4, Revalue 5, Revalue 6 are alternative explanatory variables, the investment are explanatory variables, Debt is the intermediary variable, and the rest are the control variables.

According to the accounting standards, buildings are measured at historical cost in the company's financial statements, and the explanatory variable of this article, the collateral value refers to the market value of the property owned by the listed company, which is not included in the financial statements of the listed company. In order to convert the value of the real estate measured by the listed company to the market value, first, assume that the building depreciates to the straight-line method, the depreciation period is 25 years, and then the depreciation period is multiplied by the ratio of the accumulated depreciation of the building to the original value [22]. The service life of the listed company's buildings and buildings, and then the year of purchase of the listed company's

Table 1. Variable definition.

\begin{tabular}{|c|c|}
\hline Variable & Definition \\
\hline Revalue 1 & $\begin{array}{l}\text { The Revalue } 1 \text { is equal to the market value of the Commercial Housing in } 30 \\
\text { provinces/the net amount of fixed assets that lags the first period. }\end{array}$ \\
\hline Revalue 2 & $\begin{array}{l}\text { The Revalue } 1 \text { is equal to the market value of the Residential Commercial Housing in } \\
30 \text { provinces/the net amount of fixed assets that lags the first period }\end{array}$ \\
\hline Revalue 3 & $\begin{array}{l}\text { The Revalue } 1 \text { is equal to the market value of the Commercial Business Buildings in } \\
30 \text { provinces/the net amount of fixed assets in the first period. }\end{array}$ \\
\hline Revalue 4 & $\begin{array}{l}\text { The Revalue } 1 \text { is equal to the market value of the Commercial Business Housing in } 30 \\
\text { provinces/the net amount of fixed assets that lags the first period }\end{array}$ \\
\hline Revalue 5 & $\begin{array}{l}\text { The Revalue } 1 \text { is equal to the market value of the Commercial Housing in } 36 \text { large } \\
\text { and medium-sized cities/the net amount of fixed assets that lags the first period }\end{array}$ \\
\hline Revalue 6 & $\begin{array}{l}\text { The Revalue } 1 \text { is equal to the market value of the Residential Commercial Housing in } \\
36 \text { large and medium-sized cities/the net amount of fixed assets that lags the first } \\
\text { period }\end{array}$ \\
\hline Investment & $\begin{array}{l}\text { The company's investment is equal to the construction of fixed assets, intangible } \\
\text { assets and other long-term assets paid cash }+ \text { disposal of fixed assets, intangible assets } \\
\text { and other long-term assets recovered net cash/the fixed assets that lags the first } \\
\text { period }\end{array}$ \\
\hline Debt & $\begin{array}{l}\text { The level of debt is equal to the interest-bearing liabilities/the net amount of fixed } \\
\text { assets that lags the first period }\end{array}$ \\
\hline Cashflow & $\begin{array}{l}\text { net cash flow from current operating activities/the net fixed assets that lags the first } \\
\text { period }\end{array}$ \\
\hline Size & the natural logarithm of total operating income \\
\hline Age & the number of years the company was founded \\
\hline Tobins'q & market value/total assets \\
\hline Roa & net profit/total assets balance \\
\hline Leverage & total liabilities divided by total assets \\
\hline First & the shareholding ratio of the shareholders holding the most shares \\
\hline GYG & the proportion of state-owned shares in total shares \\
\hline
\end{tabular}


buildings and buildings according to the age of the buildings. Secondly, the average sales price data of buildings from 30 provinces, municipalities and autonomous regions in China from 1999 to 2015 were selected, and the price growth rate of neighboring years was calculated as the price index of the corresponding region. The above statistics on the average sales price of real estate began in 1999. Therefore, the missing real estate price index in 1999 and before was replaced by the consumer price index (CPI) of the corresponding year. Finally, assuming that the real estate held by the company is located at the company's place of registration, the company calculates the market value of the buildings it holds based on its registered house price index.

\subsection{Source of Data and Samples}

In order to make the selected samples representability, this paper will eliminate the following samples: 1) Exclude listed companies in the financial industry, real estate industry, and construction industry according to the industry classification guidelines of the 2012 version of the CSRC; 2) Exclude Companies listed after 2002; 3) Excluding listed companies with severe data loss.

The data of the listed companies are from the fixed assets, accumulated depreciation and impairment provisions in the "Notes Database of CSMAR China Listed Companies". The liabilities of listed companies and other financial data are from "CSMAR China Listed Companies Financial Statement Data". The average price of the Commercial Housing, the average Price of the Residential Commercial Housing, the average Price of the Commercial Business Buildings in 30 provinces, and the average Price of the Commercial Business Housing, and the average price of the Commercial Housing, the average Price of the Residential Commercial Housing in 36 large and medium-sized cities are from the $\mathrm{Na}$ tional Bureau of Statistics in China.

\subsection{Descriptive Statistics}

In order to eliminate the influence of outliers, this paper performs a Winsor process on the continuous variables at the company level to eliminate the influence of outliers on the estimation results. After the variables are tailed, descriptive statistics are performed. The statistical results in Table 2 show that the average investment value is 0.3683 , and the median is only 0.1981 , which indicates that more than half of the company's investment has not reached the average level, which means that most companies have low investment levels. In addition, the average debt of the company is greater than the median, indicating that more than half of the companies are underfunded and the liabilities are not at an average level.

\section{Empirical Analysis}

\subsection{Regression Analysis}

Based on the models (1), this paper tests the relationship between collateral value and the company's investment. The empirical test results are shown in Table 3. 
Table 2. Descriptive statistics.

\begin{tabular}{ccccccc}
\hline Variable & $\mathrm{N}$ & Mean & Sd & Min & P50 & Max \\
\hline investment & 5103 & 0.3683 & 0.8367 & -1.3278 & 0.1981 & 6.8902 \\
Revalue1 & 5103 & 0.2647 & 0.7709 & 0.0001 & 0.0015 & 3.2315 \\
Revalue 2 & 5103 & 0.435 & 1.3237 & 0.0001 & 0.0017 & 5.6258 \\
Revalue3 & 5103 & 0.2409 & 0.7257 & 0 & 0.0011 & 3.0365 \\
Revalue4 & 5103 & 0.1019 & 0.2746 & 0 & 0.0011 & 1.1193 \\
Revalue5 & 4802 & 0.1836 & 0.5111 & 0 & 0.0011 & 2.1232 \\
Revalue6 & 4802 & 0.2555 & 0.7293 & 0 & 0.0013 & 3.0603 \\
Debt & 5103 & 1.6912 & 3.9403 & 0 & 0.8762 & 38.7181 \\
Roa & 5103 & 0.035 & 0.0627 & -0.2618 & 0.0325 & 0.2275 \\
Tobinq & 5014 & 1.7886 & 1.775 & 0.2221 & 1.25 & 11.6808 \\
Size & 5103 & 21.4664 & 1.4713 & 17.1883 & 21.4111 & 25.188 \\
GYG & 5103 & 0.1745 & 0.2215 & 0 & 0.0299 & 0.862 \\
First & 5103 & 0.2344 & 0.1979 & 0.0014 & 0.2175 & 0.7303 \\
Age & 5093 & 14.6476 & 5.0974 & 2 & 15 & 35 \\
Cashflow & 5103 & 0.287 & 0.818 & -3.6513 & 0.1887 & 5.2737 \\
Leverage & 5103 & 0.5206 & 0.1991 & 0.0826 & 0.5219 & 1.3738 \\
\hline
\end{tabular}

In order to study the impact of the collateral value on the company's investment, we conduct a regression analysis of the collateral value 1 (Revalue 1) and company investment. The results are shown in column (1) of Table 3. From the regression results, the estimated value of the coefficient is 0.149 , and the significance test is passed at the $1 \%$ level, indicating that there is a significant positive correlation between the collateral value 1 (Revalue 1) and the company's investment, which means that the collateral value 1 (Revalue 1) increases, the company's investment increases together. The collateral value 2 (Revalue 2), the collateral value 2 (Revalue 2), the collateral value 3 (Revalue 3 ) and the company's investment regression results are listed in column (2), (3) (4) respectively. The regression results also show that there is a significant positive correlation between the collateral value and the company's investment.

Further, based on the model (1), we add the intermediate variable, the debt, to discuss the possible mediating effects. The results are shown in Table 4. The column (1) of Table 4 shows that the estimated value of coefficient is 0.927 , and the significance test is passed at the $1 \%$ level, indicating that there is a significant positive correlation between the mortgage value 1 of housing (Revalue 1) and the debt capacity of the company, which means that the collateral value 1 (Revalue 1) increases, the company's liabilities increase together. The collateral value 2 (Revalue 2), the collateral value 2 (Revalue 2), the collateral value 3 (Revalue 3) and the debt regression results are listed in column (2), (3) (4) respectively. The regression results also show that there is a significant positive correlation between the collateral value and debt. 
Table 3. The regression results of the collateral value and company's investment.

\begin{tabular}{|c|c|c|c|c|}
\hline Variable & (1) & (2) & (3) & (4) \\
\hline & Investment & Investment & Investment & Investment \\
\hline \multirow[t]{2}{*}{ Revalue } & $0.149^{* * *}$ & $0.0820^{* * *}$ & $0.133^{* * *}$ & $0.603^{* * *}$ \\
\hline & $(4.18)$ & $(3.96)$ & $(3.88)$ & $(4.86)$ \\
\hline \multirow[t]{2}{*}{ Roa } & 0.0242 & 0.0372 & 0.0625 & -0.0846 \\
\hline & $(0.08)$ & $(0.13)$ & $(0.22)$ & $(--0.30)$ \\
\hline \multirow[t]{2}{*}{ Tobinq } & -0.000533 & 0.000580 & -0.00172 & -0.00327 \\
\hline & $(-0.03)$ & $(0.04)$ & $(-0.11)$ & $(-0.21)$ \\
\hline \multirow[t]{2}{*}{ Size } & $0.139^{* * *}$ & $0.138^{\star * *}$ & $0.136^{* * *}$ & $0.141^{* * *}$ \\
\hline & $(4.12)$ & $(4.08)$ & $(4.01)$ & $(4.16)$ \\
\hline \multirow[t]{2}{*}{ GYG } & $0.323^{\star * *}$ & $0.326^{\star * *}$ & $0.315^{\star * *}$ & $0.308^{\star * *}$ \\
\hline & $(3.30)$ & (3.33) & (3.19) & (3.19) \\
\hline \multirow[t]{2}{*}{ First } & 0.0532 & 0.0597 & 0.0513 & 0.000884 \\
\hline & $(0.32)$ & $(0.36)$ & $(0.32)$ & $(0.01)$ \\
\hline \multirow[t]{2}{*}{ Age } & $-0.0273^{\star * *}$ & $-0.0256^{* * *}$ & $-0.0228^{\star *}$ & $-0.0362^{* * *}$ \\
\hline & $(-3.01)$ & $(-2.83)$ & $(-2.49)$ & $(-3.70)$ \\
\hline \multirow[t]{2}{*}{ Cashflow } & $0.264^{\star * *}$ & $0.265^{\star * *}$ & $0.270^{* * *}$ & $0.265^{\star * *}$ \\
\hline & (5.95) & $(5.96)$ & $(6.03)$ & $(6.06)$ \\
\hline \multirow[t]{2}{*}{ Leverage } & -0.118 & -0.114 & -0.113 & -0.117 \\
\hline & $(-0.77)$ & $(-0.74)$ & $(-0.72)$ & $(-0.77)$ \\
\hline \multirow[t]{2}{*}{ _cons } & $-2.293^{\star * *}$ & $-2.289^{* * *}$ & $-2.249^{* * *}$ & $-2.239^{* * *}$ \\
\hline & $(-3.33)$ & $(-3.32)$ & $(-3.29)$ & $(-3.29)$ \\
\hline Firm & Yes & Yes & Yes & Yes \\
\hline Year & Yes & Yes & Yes & Yes \\
\hline $\mathrm{N}$ & 5004 & 5004 & 5004 & 5004 \\
\hline $\mathrm{r} 2$ & 0.121 & 0.120 & 0.118 & 0.130 \\
\hline
\end{tabular}

Note: The values in parentheses are $t$ values, and ${ }^{*},{ }^{* *}$, and ${ }^{* *}$ indicate the significance levels of $10 \%, 5 \%$, and $1 \%$, respectively.

Finally, the regression results of model (3) are shown in Table 5. The results of column (1) in Table 5 show coefficient of model (3) are 0.0365 and 0.0978 , and the coefficient passed the $1 \%$ significance test. This shows that after controlling the impact of the company's debt on the company's investment, the mortgage value of housing has a significant positive effect on the company's investment; moreover, after controlling the impact of the mortgage value on the company's investment, the company's debt capacity also has significant investment in the company. The collateral value 2 (Revalue 2), the collateral value 2 (Revalue 2), the collateral value 3 (Revalue 3 ) in model (3) are listed in column (2), (3) (4) respectively. The regression results also show that there is a significant positive correlation. 
Table 4. The regression results of the collateral value and debt.

\begin{tabular}{|c|c|c|c|c|}
\hline Variable & (1) & (2) & (3) & (4) \\
\hline & Debt & Debt & Debt & Debt \\
\hline \multirow[t]{2}{*}{ Revalue } & $0.927^{\star * *}$ & $0.506^{* * *}$ & $0.623^{* * *}$ & $3.342^{\star * *}$ \\
\hline & $(4.20)$ & $(4.07)$ & (3.04) & $(4.83)$ \\
\hline \multirow[t]{2}{*}{ Roa } & 0.964 & 1.028 & 1.330 & 0.435 \\
\hline & $(0.59)$ & $(0.63)$ & $(0.82)$ & $(0.27)$ \\
\hline \multirow{2}{*}{ Tobinq } & $-0.182^{* *}$ & $-0.175^{\star *}$ & $-0.180^{\star *}$ & $-0.194^{\star *}$ \\
\hline & $(-2.11)$ & $(-2.03)$ & $(-2.05)$ & $(-2.22)$ \\
\hline \multirow[t]{2}{*}{ Size } & $0.551^{\star *}$ & $0.544^{\star *}$ & $0.522^{* *}$ & $0.555^{\star *}$ \\
\hline & $(2.11)$ & $(2.07)$ & (1.97) & $(2.13)$ \\
\hline \multirow[t]{2}{*}{ GYG } & $1.016^{*}$ & $1.037^{\star}$ & $1.015^{\star}$ & $0.946^{*}$ \\
\hline & (1.91) & $(1.95)$ & $(1.86)$ & $(1.80)$ \\
\hline \multirow[t]{2}{*}{ First } & $3.130^{\star * *}$ & $3.169^{* * *}$ & $3.101^{* * *}$ & $2.829^{\star * *}$ \\
\hline & $(2.84)$ & $(2.87)$ & $(2.80)$ & $(2.64)$ \\
\hline \multirow[t]{2}{*}{ Age } & $-0.189^{* * *}$ & $-0.178^{* * *}$ & $-0.138^{\star \star}$ & $-0.225^{\star * *}$ \\
\hline & $(-3.32)$ & $(-3.17)$ & $(-2.46)$ & $(-3.88)$ \\
\hline \multirow[t]{2}{*}{ _cons } & -8.448 & -8.422 & -8.279 & -8.152 \\
\hline & $(-1.63)$ & $(-1.62)$ & $(-1.58)$ & $(-1.58)$ \\
\hline Firm & Yes & Yes & Yes & Yes \\
\hline Year & Yes & Yes & Yes & Yes \\
\hline $\mathrm{N}$ & 5004 & 5004 & 5004 & 5004 \\
\hline $\mathrm{r} 2$ & 0.0663 & 0.0647 & 0.0521 & 0.0780 \\
\hline
\end{tabular}

Note: The values in parentheses are $t$ values, and ${ }^{*},{ }^{* *}$, and ${ }^{* * *}$ indicate the significance levels of $10 \%, 5 \%$, and $1 \%$, respectively.

\subsection{Analysis of Mediating Effects}

Under the framework of the mediating effect, the estimated values of the coefficients corresponding to the models in the regression are shown in Figure 1.

After testing, this paper finds that there is a mediating effect between the collateral value and the company's investment with the debt capacity as the intermediate variable. Since the sum of the intermediary effect and the direct effect is not equal to the total effect, the mediating effect between the mortgage value of the real estate and the company's investment with the debt capacity as the intermediate variable is a partial mediating effect.

\subsection{Robustness Test}

In order to ensure the robustness of the research results, in addition to using the average price of the Commercial Housing in 30 provinces to calculate the collateral value of the real estate, the average price of the Residential Commercial Housing, the average price of the Commercial Business Buildings, and the 
Table 5. The regression results of the collateral value, debt and investment.

\begin{tabular}{|c|c|c|c|c|}
\hline Variable & (1) & (2) & (3) & (4) \\
\hline & Investment & Investment & Investment & Investment \\
\hline \multirow[t]{2}{*}{ Revalue } & $0.0365^{*}$ & 0.0217 & $0.0551^{* *}$ & $0.205^{* * *}$ \\
\hline & $(1.67)$ & $(1.65)$ & $(2.42)$ & $(2.68)$ \\
\hline \multirow[t]{2}{*}{ Debt } & $0.0978^{* * *}$ & $0.0979^{\star * *}$ & $0.0979^{* * *}$ & $0.0963^{* * *}$ \\
\hline & $(8.23)$ & $(8.23)$ & $(8.30)$ & $(8.10)$ \\
\hline \multirow[t]{2}{*}{ Roa } & -0.455 & -0.454 & -0.454 & $-0.494^{\star}$ \\
\hline & $(-1.59)$ & $(-1.58)$ & $(-1.60)$ & $(-1.72)$ \\
\hline \multirow[t]{2}{*}{ Tobinq } & 0.0129 & 0.0134 & 0.0111 & 0.0111 \\
\hline & $(0.85)$ & $(0.88)$ & $(0.73)$ & $(0.73)$ \\
\hline \multirow[t]{2}{*}{ Size } & $0.103^{* * *}$ & $0.103^{* * *}$ & $0.103^{* * *}$ & $0.104^{* * *}$ \\
\hline & (3.15) & (3.14) & (3.16) & (3.16) \\
\hline \multirow[t]{2}{*}{ GYG } & $0.198^{* *}$ & $0.199^{* *}$ & $0.191^{* *}$ & $0.195^{* *}$ \\
\hline & $(2.33)$ & $(2.32)$ & $(2.23)$ & $(2.29)$ \\
\hline \multirow[t]{2}{*}{ First } & $-0.275^{*}$ & $-0.272^{*}$ & $-0.271^{*}$ & $-0.290^{*}$ \\
\hline & $(-1.79)$ & $(-1.77)$ & $(-1.80)$ & $(-1.93)$ \\
\hline \multirow[t]{2}{*}{ Age } & -0.00761 & -0.00720 & -0.00944 & -0.0127 \\
\hline & $(-0.88)$ & $(-0.85)$ & $(-1.09)$ & $(-1.41)$ \\
\hline \multirow[t]{2}{*}{ Cashflow } & $0.225^{\star * *}$ & $0.225^{\star * *}$ & $0.227^{\star * *}$ & $0.225^{\star * *}$ \\
\hline & $(6.16)$ & $(6.16)$ & $(6.19)$ & $(6.18)$ \\
\hline \multirow[t]{2}{*}{ Leverage } & $-0.680^{\star * *}$ & $-0.680^{* * *}$ & $-0.675^{\star * *}$ & $-0.670^{* * *}$ \\
\hline & $(-4.45)$ & $(-4.44)$ & $(-4.37)$ & $(-4.39)$ \\
\hline \multirow[t]{2}{*}{ _cons } & $-1.533^{\star *}$ & $-1.534^{* *}$ & $-1.513^{\star *}$ & $-1.501^{\star *}$ \\
\hline & $(-2.37)$ & $(-2.37)$ & $(-2.35)$ & $(-2.33)$ \\
\hline Firm & Yes & Yes & Yes & Yes \\
\hline Year & Yes & Yes & Yes & Yes \\
\hline $\mathrm{N}$ & 5073 & 5073 & 5073 & 5073 \\
\hline $\mathrm{r} 2$ & 0.273 & 0.273 & 0.274 & 0.275 \\
\hline
\end{tabular}

Note: The values in parentheses are $t$ values, and ${ }^{*},{ }^{*}$, and ${ }^{* * *}$ indicate the significance levels of $10 \%, 5 \%$, and $1 \%$, respectively.

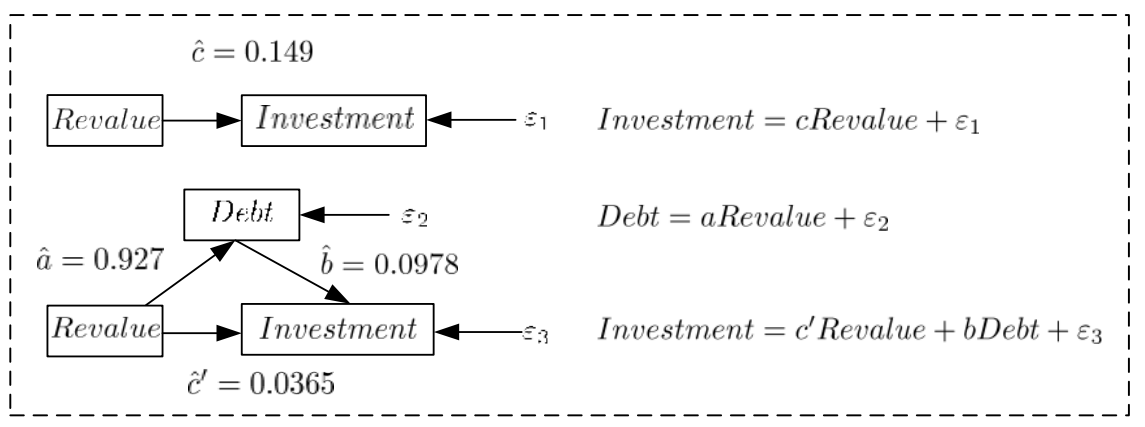

Figure 1. Analysis of Mediating Effects (Take the main results of column (1) in Table 3, Table 4, and Table 5 as examples). 
average price of the Commercial Business Housing are used. The corresponding regression results are located in column (2) (3) (4) in Table 3, Table 4, and Table 5. The regression results in Table 3, Table 4, and Table 5 indicate that the mortgage value 2 (Revalue 2) calculated by the average price of the Commercial Housing, the mortgage value 3 (Revalue 3 ) calculated by the average price of the Commercial Business Buildings, and the mortgage value 4 (Revalue 4) calculated the average housing price of the Commercial Business Housing also has a positive impact on the company's investment, and the mediating effect still exists. In other words, the collateral value influences the debt, and debt further affects corporate investment through the mediating effect.

This paper also uses the average price of the Commercial Housing in 35 large and medium-sized cities and the average price of the Residential Commercial Housing to calculate the mortgage value of the real estate. The calculated mortgage value of the real estate is represented by the collateral value 5 (Revalue 5) and the collateral value 6 (Revalue 6 ). When using the property mortgage value 5 (Revalue 5) to measure the mortgage value of the house, the regression results of the model (1) (2) (3) are located in the first three columns of Table 6. When using the collateral value 6 (Revalue 6 ) to measure the mortgage value of the property, the regression results of the model (1) (2) (3) are located in the last three columns of Table 6.

The regression results in Table 6 show that when using the collateral value 5 (Revalue 5) to measure the mortgage value of the property, the estimated values of the coefficients are $1.069,0.0573,0.0417$, and 0.0146 respectively. All coefficients passed the significance test at the $1 \%$ level. When using the collateral value 6 (Revalue 6) to measure the mortgage value of the house, the estimated values of the coefficients are $0.681,0.0357,0.0255$, and 0.0147 respectively. All coefficients passed the significance test at the $1 \%$ level.

The regression results in Table 6 can further illustrate that the collateral value is positively affecting the company's investment, and the collateral value through the debt level positively affects the company's investment is robust. In other words, the higher the mortgage value of the house, the more the company invests. In addition, the increase in the value of mortgages can increase the company's debt level, ease the financing constraints of the company, and increase the company's investment.

\section{Conclusions and Recommendations}

This paper uses the micro data of listed companies in China and the regional house price index to study the relationship between mortgage value and corporate investment and its mechanism of action. The findings are as follows. 1) Other conditions remain unchanged, and the collateral value has a significant positive impact on the company's investment. 2) According to the step-by-step test, when introducing the intermediate variable, the debt, the principle of testing the intermediary effect shows the collateral value through the debt and thus affecting 
Table 6. The regression results of the collateral value and investment (robustness test).

\begin{tabular}{|c|c|c|c|c|c|c|}
\hline & (1) & (2) & (3) & (4) & (5) & (6) \\
\hline Variable & Investment & Debt & Investment & Investment & Debt & Investment \\
\hline \multirow[t]{2}{*}{ Revalue 1} & $1.605^{\star * *}$ & $0.308^{* * *}$ & $0.145^{\star * *}$ & $0.967^{\star * *}$ & $0.183^{\star * *}$ & $0.0828^{\star *}$ \\
\hline & $(4.52)$ & $(5.40)$ & $(2.75)$ & $(4.13)$ & $(4.95)$ & $(2.38)$ \\
\hline \multirow[t]{2}{*}{ Debt } & & & $0.102^{\star * *}$ & & & $0.103^{\star * *}$ \\
\hline & & & $(7.51)$ & & & $(7.58)$ \\
\hline \multirow[t]{2}{*}{ roa } & 0.557 & -0.0255 & $-0.524^{*}$ & 0.793 & 0.0263 & -0.501 \\
\hline & $(0.31)$ & $(-0.08)$ & $(-1.67)$ & $(0.45)$ & $(0.08)$ & $(-1.61)$ \\
\hline \multirow[t]{2}{*}{ tobinq } & $-0.184^{*}$ & -0.000963 & 0.0153 & $-0.180^{*}$ & -0.0000873 & 0.0159 \\
\hline & $(-1.86)$ & $(-0.06)$ & $(0.95)$ & $(-1.82)$ & $(-0.01)$ & $(0.98)$ \\
\hline \multirow[t]{2}{*}{ Size } & $0.579^{* *}$ & $0.156^{\star * *}$ & $0.115^{\star * *}$ & $0.564^{\star *}$ & $0.153^{* * *}$ & $0.113^{\star * *}$ \\
\hline & $(2.03)$ & $(4.30)$ & $(3.23)$ & $(1.97)$ & $(4.19)$ & (3.17) \\
\hline \multirow[t]{2}{*}{ GYG } & 0.604 & $0.258^{* *}$ & $0.155^{*}$ & 0.636 & $0.265^{\star * *}$ & $0.158^{*}$ \\
\hline & (1.18) & $(2.57)$ & $(1.76)$ & $(1.24)$ & $(2.61)$ & (1.79) \\
\hline \multirow[t]{2}{*}{ First } & $2.526^{* *}$ & -0.0210 & -0.256 & $2.614^{\star *}$ & -0.00463 & -0.250 \\
\hline & $(2.28)$ & $(-0.12)$ & $(-1.61)$ & $(2.35)$ & $(-0.03)$ & $(-1.56)$ \\
\hline \multirow[t]{2}{*}{ Age } & $-0.219^{\star * *}$ & $-0.0399 * * *$ & $-0.0210^{\star *}$ & $-0.191^{\star \star \star}$ & $-0.0341^{\star * *}$ & $-0.0178^{\star}$ \\
\hline & $(-3.57)$ & $(-4.12)$ & $(-2.20)$ & $(-3.15)$ & $(-3.52)$ & $(-1.91)$ \\
\hline \multirow[t]{2}{*}{ Cashflow } & & $0.241^{\star * *}$ & $0.211^{\star * *}$ & & $0.243^{\star * *}$ & $0.212^{* * *}$ \\
\hline & & (5.39) & $(5.73)$ & & $(5.42)$ & (5.76) \\
\hline \multirow[t]{2}{*}{ Leverage } & & -0.102 & $-0.637^{\star * *}$ & & -0.0930 & $-0.636^{* * *}$ \\
\hline & & $(-0.66)$ & $(-4.11)$ & & $(-0.60)$ & $(-4.10)$ \\
\hline \multirow[t]{2}{*}{ _cons } & -8.654 & $-2.516^{* * *}$ & $-1.678^{* *}$ & -8.600 & $-2.501^{\star * *}$ & $-1.665^{\star *}$ \\
\hline & $(-1.55)$ & $(-3.44)$ & $(-2.44)$ & $(-1.53)$ & $(-3.41)$ & $(-2.41)$ \\
\hline Firm & Yes & Yes & Yes & Yes & Yes & Yes \\
\hline Year & Yes & Yes & Yes & Yes & Yes & Yes \\
\hline $\mathrm{N}$ & 4718 & 4718 & 4718 & 4718 & 4718 & 4718 \\
\hline $\mathrm{r} 2$ & 0.0653 & 0.114 & 0.264 & 0.0591 & 0.110 & 0.263 \\
\hline
\end{tabular}

Note: The values in parentheses are $t$ values, and ${ }^{*},{ }^{* *}$, and ${ }^{* * *}$ indicate the significance levels of $10 \%, 5 \%$, and $1 \%$, respectively.

the company's investment is significant, but the mechanism is part of the mediating effect, not the full mediating effect. 3) When we use other types of housing price, there is still a significant positive relationship between the collateral value and the company's investment, which indicates that the same conclusion is obtained.

The research in this paper shows that the collateral value has a significant positive impact on the company's investment, and one quarter of the total effect of the mortgage value of the property on the company's investment is achieved through the mortgage channel effect. At present, China's housing prices remain high, and the provincial and district governments have implemented price control 
measures in various regions in order to protect the interests of residents and achieve a balance between supply and demand in the real estate market. The slogan of "adhering to the uncontrolled development of the property market" is not uncommon. Although high housing prices may reduce the overall welfare level of society, our research proves that there is a positive relationship between housing price changes and corporate investment. The rapid decline in housing prices may lead to a significant decline in corporate mortgage assets, thereby weakening corporate investment. This in turn affects the allocation and production of enterprise resources and even harms the overall economy. Therefore, this paper suggests that while adopting house price regulation measures to curb the irrational growth of house prices, we must also take effective measures to encourage companies to increase corporate investment and improve resource allocation efficiency. Furthermore, the inspiration of the collateral value through the mediating effect affects the company's investment mechanism is that governments at all levels can consider reducing the financing difficulty of listed companies and alleviating the company's financing constraints through offsetting the mortgage value of the house to avoid the negative impact of the decline in the company's investment through the effect of the mortgage channel.

\section{Conflicts of Interest}

The author declares no conflicts of interest regarding the publication of this paper.

\section{References}

[1] Sun, B. (2010) China's Housing Price Bubble Scale and Development Trend. Academic Exchange, 4, 111-114.

[2] Li, L. (2010) A Literature Review of the Transmission Effect of the Real Estate Market on Consumer Spending. Economic Theory and Economic Management, 11, 40-46.

[3] Goodhart, C. and Hofmann, B. (2007) House prices and the Macroeconomy: Implications for Banking and Price Stability. Oxford University Press, Oxford.

[4] Kiyotaki, N. and Moore, J. (1997) Credit Cycles. Journal of Political Economy, 105, 211-248. https://doi.org/10.1086/262072

[5] Tan, Z.X. and Chen, M. (2012) International Empirical Evidence of Housing Price Volatility and Financial Crisis: Mortgage Effect or Deviation Effect. World Economy, 3, 146-159.

[6] Chaney, T., Sraer, D. and Thesmar, D. (2012) The Collateral Channel: How Real Estate Shocks Affect Corporate Investment. American Economic Review, 102, 2381-2409. https://doi.org/10.1257/aer.102.6.2381

[7] Lamont, O. (1997) Cash Flow and Investment: Evidence from Internal Capital Markets. The Journal of Finance, 52, 83-109. https://doi.org/10.1111/j.1540-6261.1997.tb03809.x

[8] Gan, J. (2007) Collateral, Debt Capacity, and Corporate Investment: Evidence from a Natural Experiment. Journal of Financial Economics, 85, 709-734.

https://doi.org/10.1016/j.jfineco.2006.06.007 
[9] Zeng, H.J. (2012) Real Estate Value and Changes in the Company's Investment and Financing-China's Empirical Evidence of the Effect of Mortgage Guarantee Channel. Management World, No. 5, 125-136.

[10] Catherine, S., Chaney, T., Huang, Z., Sraer, D. and Thesmar, D. (2017) Aggregate Effects of Collateral Constraints. Working Paper. https://economics.stanford.edu/sites/g/files/sbiybj9386/f/thesmar.pdf

[11] MacKinnon, D.P., Warsi, G. and Dwyer, J.H. (1995) A Simulation Study of Mediated Effect Measures. Multivariate Behavioral Research, 30, 41-62. https://doi.org/10.1207/s15327906mbr3001_3

[12] Fisher, I. (1933) The Debt-Deflation Theory of Great Depressions. Econometrica: Journal of the Econometric Society, 1, 337-357. https://doi.org/10.2307/1907327

[13] Bernanke, B.S., Gertler, M. and Gilchrist, S. (1999) The Financial Accelerator in a Quantitative Business Cycle Framework. Handbook of Macroeconomics, 1, 1341-1393. https://doi.org/10.1016/S1574-0048(99)10034-X

[14] Tirole, J. (2010) The Theory of Corporate Finance. Princeton University Press, Princeton.

[15] Benmelech, E., Garmaise, M.J. and Moskowitz, T.J. (2005) Do Liquidation Values Affect Financial Contracts? Evidence from Commercial Loan Contracts and Zoning Regulation. The Quarterly Journal of Economics, 120, 1121-1154.

[16] Schmalz, M.C., Sraer, D.A. and Thesmar, D. (2013) Housing Collateral and Entrepreneurship (No. w19680). National Bureau of Economic Research, Cambridge, MA. https://doi.org/10.3386/w19680

[17] Benmelech, E. and Bergman, N.K. (2008) Liquidation Values and the Credibility of Financial Contract Renegotiation: Evidence from US Airlines. The Quarterly Journal of Economics, 123, 1635-1677. https://doi.org/10.1162/qjec.2008.123.4.1635

[18] Almeida, H. and Campello, M. (2007) Financial Constraints, Asset Tangibility, and Corporate Investment. The Review of Financial Studies, 20, 1429-1460. https://doi.org/10.1093/rfs/hhm019

[19] Wu, Y. (2016) Property Mortgage Value and Corporate Investment. Ph.D. Thesis, Jinan University, Guangzhou.

[20] Luo, S.K. and Zhou, Y.H. (2013) Does Housing Prices Affect Corporate Investment: Theory and Evidence. Financial Research, 39, 133-144.

[21] Bester, H. (1985) Screening vs. Rationing in Credit Markets with Imperfect Information. The American Economic Review, 75, 850-855.

[22] Nelson, T.R., Potter, T. and Wilde, H.H. (2000) Real Estate Assets on Corporate Balance Sheets. Journal of Corporate Real Estate, 2, 29-40. https://doi.org/10.1108/14630010010811185 